University of Nebraska - Lincoln

DigitalCommons@University of Nebraska - Lincoln

November 2006

\title{
Deracialization or Racialization: The Making of a Black Mayor in Jackson, Mississippi
}

Byron D. Orey

borey2@unl.edu

Follow this and additional works at: https://digitalcommons.unl.edu/poliscifacpub

Part of the Political Science Commons

Orey, Byron D., "Deracialization or Racialization: The Making of a Black Mayor in Jackson, Mississippi" (2006). Faculty Publications: Political Science. 18.

https://digitalcommons.unl.edu/poliscifacpub/18

This Article is brought to you for free and open access by the Political Science, Department of at DigitalCommons@University of Nebraska - Lincoln. It has been accepted for inclusion in Faculty Publications: Political Science by an authorized administrator of DigitalCommons@University of Nebraska - Lincoln. 


\section{Deracialization or Racialization: The Making of a Black Mayor in Jackson, Mississippi ${ }^{1}$}

\section{Byron D'Andra Orey}

University of Nebraska, Lincoln

In 1997, Harvey Johnson made history by becoming the first black to be elected as mayor of Jackson, Mississippi. Four years prior, Johnson failed to make the Democratic primary runoffs. The following research question is addressed: what explains Johnson's victory in 1997, when compared to his defeat in 1993? In answering this question, I rely heavily on elite-level interviewing and newspaper accounts. I also examine the black and white vote for Johnson, using aggregate-level election and census data. Gary King's Ecological Inference technique is used to examine these data. Based on the findings, I conclude that Johnson ran a deracialized campaign in 1993 and a racialized campaign in 1997. The deracialized campaign failed to attract white voters and attenuated his black support. In 1997, however, he was able to almost double his support from black voters. This increase can be attributed in part to his racialized campaign strategy.

\section{Lord have mercy! We're going to have a black mayor in Jackson,} Mississippi.

\section{—An anonymous black woman quoted in Chappell $(1997,76)$}

On May 3, 2005, Harvey Johnson was soundly defeated in the Democratic primary for mayor of Jackson, Mississippi, thereby ending his eightyear tenure as mayor of that city. In 1997 Johnson made history by becoming the city's first African-American mayor. Johnson's victory is of particular interest, given Jackson's infamous history in the area of race relations. As the capital of Mississippi, Jackson is well known for its massive resistance to civil rights. Indeed, the above epigraph expresses the shock felt within the black community upon Johnson's election.

Four years prior to Johnson's victory, he was defeated in the Democratic primary for that same office. One of the questions posed in the current re- search is what produced the difference between Johnson's victory in 1997 and his defeat in 1993 in this majority black city? ${ }^{2}$ One potential answer is rendered by the subtitle of an article in Jackson's major newspaper, The Clarion Ledger, on the day after Johnson's victory in the Democratic primary in 1997. It read, "[n]ew approach wins race for Johnson" (Stringfellow 1997, 1A). Implied in this "new approach" is the notion that Johnson ran a deracialized (or race-neutral) campaign in 1993 and lost, then ran a racialized (or race-specific) campaign in 1997 and won. The article specifically suggests that Johnson's (1997) campaign was similar to the one Harold Washington ran in the 1983 Chicago mayoral election, an election categorized by many scholars as a racialized campaign (see e.g., Albritton et al. 1996). My primary purpose in this article is to compare and contrast the 1993 and 1997 campaigns run by Johnson, to test whether his newly adopted campaign strategy served as the impetus behind his victory in 1997. In the following sections, I examine the extant literature on the topic of deracialization and race-specific campaigns, discuss the data and methods employed, summarize the findings, and consider what these findings imply about the use of deracialized or racialized campaigns in the area of black politics.

\section{Deracialized or Racialized Campaign Strategies?}

On November 7, 1989, L. Douglas Wilder (Virginia), David Dinkins (New York, New York), Norman Rice (Seattle, Washington), and John Daniels (New Haven, Connecticut) all made history by becoming the first black to be elected as chief executive of their respective political jurisdictions (Perry 1990). During that same year, a total of eight African Americans were elected as mayors of major American cities and one was elected as governor. The success achieved by these candidates led McCormick (1989) to label this day "black Tuesday." According to Perry (1990), of the nine candidates elected, four ran deracialized campaigns. Deracialized campaigns are typically run in majority white jurisdictions, whereby minority candidates minimize the use of race in an effort to attract white electoral support.

McCormick and Jones (1993) provide a definition of deracialization to denote situations in which black candidates, in particular, avoid using any "explicit reference to race-specific issues, while at the same time emphasizing those issues that are perceived as racially transcendent" (76). Additionally, these authors state that a deracialized political strategy affects the 
issues candidates stress, their mobilization tactics, and the style of their campaigns (McCormick and Jones 1993). When running a deracialized campaign, black candidates, they argue, should avoid using explicit references to issues such as welfare, affirmative action, and set-asides. Rather, they should place emphasis on issues that appear to be race-neutral. The second aspect of a deracialized strategy involves the campaign tactics employed by black candidates to mobilize voters. The authors contend that black office seekers should avoid public appeals to the black community. In addition, black candidates do not want to give whites the impression that they are only interested in representing blacks. The final component emphasized by the authors is political style. The success of black candidates in attracting white support depends in part on their ability to project a nonthreatening image. It is therefore necessary for black candidates to project a reassuring image to the white electorate. Black candidates, for example, should avoid associating themselves with people that white voters will view as racial partisans.

A race-specific campaign, in contrast, is defined as one in which "one candidate calls attention to the race of his or her opponent or opponent's supporters or if the news media covering a campaign disproportionately call attention to the race of one candidate or of that candidate's supporters" (Paul Luebke cited in Grofman, Handley, and Niemi 1992, 107-8). Indeed, Reeves $(1997,21)$ points out, "campaign appeals that heighten the salience of race are injected into election contests not exclusively by political candidates and their operatives but by news media organizations as well."

\section{The Evolution of the Deracialization Concept}

Charles Hamilton first introduced the concept "deracialization" in 1973 at a National Urban League meeting. The purpose of the meeting was to have a group of scholars, activists, and public officials discuss strategies for the organization in the "post-protest" phase of the civil rights movement. During this meeting Hamilton presented a brief essay that addressed some of these possible strategies. He suggested that an effort should be made to gain strategic support from those outside of the black community, especially from whites (Hamilton 1973). In an effort to gain white support, Hamilton indicated that blacks should address social issues that appeal to society as a whole. For Hamilton, one such issue was "full employment," which he considered the most important issue facing the black community and also an issue that might appeal to whites. Hamilton labeled this strategy as a "deracialized" approach that would gain white support.

In 1976, Hamilton again addressed the concept of deracialization. This time, in a position paper commissioned by the Democratic Party, he advised presidential candidates to emphasize issues that would have an appeal across racial lines (Hamilton 1977). Arguing that programs targeted directly to minorities lose votes, he urged civil rights groups and the Democratic Party to work for "deracialized solutions" such as national health insurance and an income maintenance program (McCormick and Jones 1993, 70). William Julius Wilson (1990) expanded upon Hamilton's message by suggesting that the Democratic Party embrace a progressive "race neutral program." Wilson stated that blacks and liberals who have pushed "a race-specific agenda" (e.g., affirmative action, minority set-asides, busing) create a major barrier to those advocating broader programs that would be more attractive to white voters.

In their application of the deracialization concept, two local observers of L. Douglas Wilder's 1989 Virginia gubernatorial campaign, Charles Jones and Michael Clemons, note that Wilder presented himself as a "social moderate and fiscal conservative who represented the "New Virginia Mainstream' - a major theme of the campaign" (Jones and Clemons 1993, 140). An investigation of Wilder's appointment book disclosed that between June 19 and September 4, 1989, Wilder appeared before the public 84 times. Jones and Clemons identify the groups Wilder addressed as being predominantly white or predominantly black and report that only ten of these appearances were before black audiences.

Schexnider (1990) contends that Wilder's deracialization strategy can be traced back as far as his 1985 campaign to become lieutenant governor of Virginia. In Schexnider's view, Wilder did not present himself to the Virginia electorate as a black candidate in 1985. Based on the author's account, Wilder focused on his legislative record, and economic, educational, and environmental issues that appealed to all voters (Schexnider 1990, 155). Schexnider points to the work of Yancey (1988) as support for his claims. He quotes Yancey as stating that 
Wilder never mentioned race. He hammered away at why he was more qualified until the media and white voters finally had to pay attention. But his campaign never took on the aura of a black crusade. But Wilder knew he had to have the redneck and suburban vote to win and he went after it (Yancey 1988, quoted in Schexnider 1990, 155).

In 1983, Wilson Goode was elected as the first black mayor of Philadelphia, Pennsylvania. According to Ransom (1987), Goode achieved this feat by not running as a black candidate. "Goode did not portray himself as a 'black' candidate for mayor; instead, he campaigned as the former city managing director - he was familiar with city services; he knew the budget; he had demonstrated his managerial skills; and he had a vision of Philadelphia on the move" (276). Ransom goes on to state that Goode placed emphasis on his experience and background, and voiced the necessity of a partnership between the public and private sectors, but failed to reference any evidence to support these claims.

\section{Deracialization and Its Limitations as a Campaign Strategy}

The deracialization strategy gained increased attention following the success of black candidates on "black Tuesday." The strategy, however, has not always ended in success. While Andrew Young was successful as an Atlanta mayor in using a deracialized strategy to build a coalition between the white business-elites and the black middle-class, this strategy failed to mobilize support from either blacks or whites in his 1990 bid for governor.

Why was Young unable to mobilize the black vote? According to Pierannunzi and Hutcheson (1996), many of Young's previous black supporters were dissatisfied with his tenure as mayor. During Young's campaign for governor he was highly criticized by homeless advocates for his displacement of mainly black residents during the construction of an Olympic stadium (98). Black ministers and black-elected officials criticized him for his ties to the business elites (99). Young maintained his connections with the business elites during the governor's race by seeking campaign contributions from major corporations such as Delta Airlines and Coca-Cola. In seeking these donations, as well as his efforts to appeal to white voters, Pierannunzi and Hutcheson (1996) suggest that Young ran a deracial- ized campaign. In one instance, he mentioned that racism in Georgia was once like "cancer" but was now like "acne." His successful white opponent, Zell Miller, rebutted by claiming that racism was increasing. Despite the lack of emphasis on race by Young, he was able to garner only 15 percent of the white vote. More important, voter turnout of whites was reportedly higher than anticipated and the black turnout was very low (although Pierannunzi and Hutcheson 1996, 100 fail to provide any figures for voter turnout). In short, Young appeared to have lost more than he gained by running a deracialized campaign. He failed to mobilize his much needed black support and also failed to capture a significant amount of the white vote. This was blamed largely on his deracialized campaign strategy (Pierannunzi and Hutcheson 1996). ${ }^{3}$

\section{Race-Specific Campaigns}

Pohlman and Kirby (1996, xxi) contend that candidates who make deracialized appeals are seen by blacks as naive at best or as "selling out at worst." These authors conclude that the election of Dr. Willie Herenton as mayor of Memphis, Tennessee in 1991 is inconsistent with the notion that a black candidate should run a deracialized campaign if $\mathrm{s} / \mathrm{he}$ is to be successful in a racially competitive jurisdiction. Memphis serves as an interesting case given the racial makeup of the city. As of 1990, blacks constituted 54 percent of the total population and 51 percent of the voting age population. The authors document previous failed attempts by black candidates in Memphis who allegedly ran deracialized mayoral campaigns (Pohlman and Kirby 1996, 23-4, 94; see also Wright 1996, 152-4). As a result of these failed attempts, the authors maintain, Herenton relied primarily on the mobilization of black support in his successful bid for mayor. Herenton's almost exclusive dependency on the black electorate was due to the absence of a liberal white community located in Memphis. According to Pohlman and Kirby $(1996,200)$, "political reality severely limited the chances of deracialized city politics, at least at the mayoral level."

The failure of the deracialized campaigns by previous candidates in Memphis makes that case very similar to that of Jackson studied here. While Herenton was able to learn from the previous mistakes of other mayoral candidates, Harvey Johnson may have learned from his own previous mistakes in 1993 as he emerged as the first black mayor of Jackson in 1997 (although see Coleman and Hudson 2001). According to the 
United States Census, as of 1990, the population of Jackson was 56 percent black and its voting age population was 51 percent black. The black population in Jackson is very similar to that of Memphis. Also, as was the case in Memphis, racially polarized voting has been documented to exist in Jackson (see Parker 1990, 136-42).

One of the most well-known race-specific campaigns was that conducted by Harold Washington for mayor of Chicago in 1983 (Albritton et al. 1996). Grimshaw (1992) argues that Washington established a broad base in the black church, the black community's historic institution of protest. ${ }^{4}$ When Washington entered the 1983 mayoral campaign, he relied heavily on the firm moral base in the black church, and a solid political organization in the black wards.

Glaser (1996) provides evidence that Mississippi Congressman Bennie Thompson also was successful in running a racialized campaign. Glaser states that "Bennie Thompson ran an unapologetic racial campaign oriented toward blacks and virtually ignored the white minority (169)." Glaser cites an increased black population in the district and the low white vote received by black former Congressman Mike Espy in his first election as reasons for Thompson's strategy (16). ${ }^{5}$

\section{Data and Methods}

This article relies on both quantitative and qualitative methods. Data employed are derived from personal interviews, campaign materials, print media, 1990 U.S. Census data, and election returns related to the 1993 and 1997 Democratic primaries for the office of mayor in Jackson, Mississippi. Information regarding the campaigns run by Harvey Johnson was gathered through elite-level interviews with political observers (e.g., political scientists and newspaper reporters) and people who worked in Harvey Johnson's campaign.

The quantitative analysis incorporated in the current research examines the estimated white and black support for Johnson. Precinct-level election returns and the racial composition of the voting age population of precincts are employed to determine whether Johnson received an increase or a decrease in his black and white support between the 1993 and the 1997 elections. It is argued here that a deracialized campaign in 1993 may have limited Johnson's black support without pro- ducing much white support, while a race-specific campaign in 1997 may have strengthened his black support sufficiently to win. The election returns were collected from the city clerk's office in Jackson and the racial compositions of the voting age populations in the various precincts were collected from the U.S. Bureau of the Census. The levels of black and white voter support for Johnson are estimated using Gary King's method of ecological inference (King 1997). This method is based on modeling random parameters for each precinct within the city (see e.g., Palmquist and Voss 1997). ${ }^{6}$

All of the quantitative data are aggregate-level data and are collected at the precinct level. Unfortunately, reliable individual-level data are not available for this analysis. The general problem of moving from data on aggregated tabulation units to data on individuals is known as the problem of ecological inference. Given the use of aggregate-level data, we must acknowledge that we are confronting the "ecological fallacy"- the possibility of making false inferences about individuals from aggregate data. Gary King $(1997,94){ }^{7}$ however, has proposed a method designed to specifically "correct for aggregation bias," thereby reducing the potential of falling prey to the ecological fallacy. King's method expands upon the Duncan-Davis method of bounds and incorporates the deterministic method of bounds with maximum likelihood estimates.

Table 1 provides a brief overview of the model and technique used to derive our estimates. According to Table 1, we can take advantage of the

Table 1. The Ecological Inference Problem

\begin{tabular}{llll}
\hline Race & Johnson & Vote Choice Other Candidates & Voting Age Population \\
& & & \\
Black & $B_{i}^{b}$ & $1-B_{i}^{b}$ & $\mathrm{X}_{\mathrm{i}}$ \\
White & $B_{i}^{w}$ & $1-B_{i}^{w}$ & $1-\mathrm{X}_{\mathrm{i}}$ \\
& $\mathrm{T}_{\mathrm{i}}$ & & $1-\mathrm{T}_{\mathrm{i}}$ \\
\hline
\end{tabular}

Note: In each precinct, noted as $\mathrm{i}$, both $\mathrm{X}_{\mathrm{i}}$ (fraction of the voting age population who are black) and $T_{i}$ (fraction of the voting age population who voted in the referendum), along with $\mathrm{N}_{\mathrm{i}}$ not shown here (the number of voting age people, not included in the table), are observed. $B_{i}^{b}$ (fraction of voting age blacks who voted) and $B_{i}^{w}$ (fraction of voting age whites who voted) are unobserved and are inferred from the aforementioned aggregate variables. 
only observable data that we have, those data in the marginal cells, and work our way back to those unobservable quantities within the body of the table. Based on Table 1, $X_{\mathrm{i}}$ represents the fraction of the voting age population who are black and $T_{i}$ represents the proportion of the voting age population who voted for Johnson. The unobservable quantities of interest are $B_{i}^{b}$, the proportion of blacks who voted for Johnson, and $B_{i}^{w}$, the proportion of Whites who voted for Johnson. These two estimates are calculated using the estimation procedure, EI, developed by King (1997). ${ }^{8}$

\section{The Failure of the Deracialization Strategy: The 1993 Democratic Primary}

Consistent with the work of McCormick and Jones (1993), this article compares and contrasts the campaign style, issues, and mobilization tactics used by Johnson in both 1993 and 1997. Recall that in a deracialized campaign, a black candidate attempts to project a nonthreatening style so that he/she does not alienate white voters. As the Executive Director for the Mississippi Institute for Small Towns, a nonprofit organization which has developed and implemented water, sewer, and housing projects for communities throughout Mississippi, a member of the Board of Directors of Union of Planters Bank of Central Mississippi, a member of the State Tax Commission and a member of a multitude of other professional organizations and public commissions, Johnson portrayed himself as a professional. He did not have experience in the civil rights movement, and did not engage in the "confrontational mold of the traditional black politician" (Llorens, Parsons, and Perry 1996, 112).

Johnson adopted a campaign style that intended to be nonthreatening to whites during his 1993 campaign. He was very careful about which blacks he aligned himself with. A case in point was his decision not to participate in the Grassroots Political Convention. In 1992 the Citywide Coalition for a Progressive Jackson (CCPJ), an organization that was created for the sole purpose of reducing to one the number of black candidates running in the Democratic primary for mayor, sponsored the Grassroots Political Convention. The convention was to be a medium through which a choice of a black mayoral candidate could be reached. In the view of the convention's organizer, Ali Shamsid-Deen, the formation of this coalition spawned from a need to elect a candidate who would "place a priority on the problems currently destroying the African-American community" (cited in Stringfellow 1992, 1A). Shamsid-Deen has pointed to the successful employment of the People's Convention to elect Willie Herenton as the first black mayor of Memphis in 1991 as a "turning point" for his decision to initiate the organization (Pohlman and Kirby 1996, chapter 7; Uthoff 1992, A1). The most immediate impetus that drove Shamsid-Deen's decision, however, was the dissatisfaction within the black community over the white incumbent mayor's (Kane Ditto) firing of David Walker, the city's first black Police Chief (Shamsid-Deen 1999a, personal interview, March 18; Uthoff 1992, B1). The CCPJ unsuccessfully lobbied to have Walker reinstated (Uthoff 1992, 1A). According to Shamsid-Deen (1999a), Walker was perceived by the black community as having had a major impact on the reduction of drug trafficking in the city, and therefore blacks were very dissatisfied with the mayor's decision. Again, the coalition's strategy to hold a convention was based on a similar strategy employed by black residents in Memphis in their efforts to elect a black mayor in 1991. In fact, some members of the Memphis coalition assisted in organizing the Jackson convention (Shamsid-Deen 1999a; see Uthoff 1992, B1).

The "black-only" nature of the meeting left some blacks feeling uncomfortable. Following criticism from the media for not allowing white residents to attend its meetings, The Clarion Ledger reported that the CCPJ expanded to include whites and went on to say that four whites attended a meeting sponsored by the CCPJ, held on May 9, 1992 (Howard 1993, A1). Further, the headline of a May 19, 1992, article by The Clarion Ledger, read: "Coalition open to whites living in black areas" (Campbell 1992, A1).

The Grassroots Political Convention was advertised in the Jackson Advocate, the city's largest black newspaper, and The Clarion Ledger ran a number of stories prior to it. No official invitations were sent out. The convention was convened at 10:00 a.m. on August 29, 1992, at the Masonic Temple, located at 1072 Lynch Street, Jackson, Mississippi. While both Shamsid-Deen and Henry Kirksey, the candidate who received the endorsement of the convention, indicate that no whites attended the convention (Kirksey 1999; Shamsid-Deen 1999b), The Clarion Ledger reported that "a handful" of whites were in attendance (Aden 
1992, A1). The activities sponsored at the convention included voter registration, fund-raising, speeches, and the nominations. Only registered voters were allowed to participate in the nominating and voting processes. Those not registered, however, were allowed to fill out registration forms on-site. Approximately 200 people participated in the nominating and balloting process (Aden 1992, A1). Credell Calhoun, a candidate in the 1989 mayoral race and a former state representative, and Henry Kirksey, a noted civil rights activist, a former state senator and a candidate for mayor in 1981 and 1985, were the only people nominated. After the nominations, members of the CCPJ were given the opportunity to vote between the two candidates. Kirksey emerged as the victor, receiving 68 percent of the votes.

Johnson opted not to participate in the convention. According to Shamsid-Deen, who was responsible for contacting potential nominees, Johnson told him that if he participated in the convention "he would not be able to get the support of the white community and that they [CCPJ] were announcing their candidate too soon" (Shamsid-Deen 1999a). Assuming that he would emerge as the winner, Johnson stated that "[h]e would be exposed to the white media too long". The Clarion Ledger also reports that Johnson "found it more advantageous to stay out" (Fisher 1997, A19) of the convention. In a separate article in The Clarion Ledger, Johnson stated, "I think it's important to have a mayor who is sensitive to the needs and interests of all the parts of this city" (cited in Campbell 1992, A1), when responding to a question regarding him not participating in the convention.

According to Charles Tisdale (1999), the editor of the Jackson Advocate, following the convention's election of Henry Kirksey, some black leaders personally asked Johnson not to enter the mayor's race. Johnson ignored the plea of these leaders and announced his candidacy for mayor on October 27, 1992.

While the above evidence supports the notion that Johnson adopted a campaign style in 1993 intended to be nonthreatening to whites, other elements considered critical to a deracialized strategy need to be examined as well. In a deracialized campaign the candidate seeks to downplay issues that are racially divisive and emphasize issues that are "racially transcendent." In the 1993 campaign, Johnson ran on the issues of crime, eco- nomic development, and race relations (Johnson 1998). Johnson's focus on crime and economic development can be categorized as racially transcendent (see e.g., Lorens, Parsons, and Perry 1996, 111).

Jones and Clemons $(1993,76)$ state that candidates who run deracialized campaigns should avoid using "direct racial appeals" in their efforts to organize the black community. In applying a deracialization strategy, Johnson's campaign in 1993 failed to employ a strong mobilization strategy for blacks. According to Jackson State University professor, Mary Coleman, "[t]he campaign for Johnson is a week late on everything . . . Some would say a year late" (cited in Howard 1993, A1). Indeed, because of limited resources, Johnson did not begin running television advertisements until the week of the election. Due to the lack of resources, he also was unable to print any push cards, and he was only able to have a small number of placards printed in 1993. Johnson's mobilization strategy relied mainly on his visits to black churches, a strategy that has been classified as deracialized (see Jones and Clemons 1993, 141). Jones and Clemons contend that this is a "low-visibility" strategy that is "less threatening to the white electorate," compared to a strategy that would seek to publicly mobilize blacks (141).

\section{Racial Voting in the 1993 Democratic Primary for Mayor}

In 1993, six candidates entered the race for mayor of Jackson. They included five Democrats and one Republican. Among the five Democrats were two whites and three African Americans. The two white Democratic candidates were the incumbent mayor, Kane Ditto, and a former, three-term mayor who held that office from 1977 to 1989, Dale Danks. The three African-American Democratic candidates were former state Senator and noted civil rights activist, Henry Kirksey, an urban planner and Executive Director of the Mississippi Institute for Small Towns, Harvey Johnson, and a Jackson State University undergraduate student, Courtney Paige. The lone Republican candidate in the election was Al Roland, a gas station attendant. The Democratic primary was a close contest between Ditto, Danks, and Johnson. ${ }^{9}$ Ditto finished with 34 percent of the vote, Danks with 32 percent, and Johnson with 24 percent. Kirksey received only nine percent of the vote, and Paige roughly one percent. Ditto and Danks were forced into a runoff. Ditto won the runoff, receiving 62 percent of the vote to Danks's 
Table 2. 1993 Mayoral Democratic Primary (Estimated Percentage of Vote by Race)

\begin{tabular}{lccccc}
\hline & Johnson & Ditto & Danks & Kirksey & Paige \\
Blacks & 46 & 25 & 9 & 19 & 1 \\
& $(.2)$ & $(.2)$ & $(.1)$ & $(.2)$ & $(1)$ \\
Whites & 7 & 41 & 51 & 1 & .001 \\
$\mathrm{~N}=93$ & $(.2)$ & $(.3)$ & $(.2)$ & $(1)$ & $(.0001)$ \\
\hline
\end{tabular}

Note: Estimates were produced using Gary King's EI. Numbers in parenthesis are rounded estimated standard errors.

38 percent. In the general election Ditto won by a landslide, receiving 85 percent of the vote.

According to the results in Table 2, the black vote was divided among four candidates during the 1993 Democratic primary. Johnson (African American) received the highest percentage, 46, followed by the incumbent, Kane Ditto (white), with 25 percent, Kirksey (African American) with 19 percent, and Dale Danks (white), a former mayor, with only 9 percent. Paige (African American), a college student, received virtually no black or white support.

Whites provided roughly 92 percent of their vote to the white candidates and approximately only eight percent to the black candidates. The preferred candidate of the white community was the former mayor, Danks, who garnered 51 percent of the white vote, while the incumbent mayor, Ditto, finished second among white voters with 41 percent, followed by Johnson with seven percent and Kirksey with one percent.

\section{A Race-Specific Campaign: The 1997 Democratic Primary}

Johnson cites his campaign experience in 1993 as the basis for his victory in 1997 (see Fisher 1997, A19). For Johnson, "[y]ou learn from your mistakes" (cited in Fisher 1997, A19). As stated above, one of Johnson's most critical mistakes in the 1993 campaign was that he neglected the black vote in an effort to attract white crossover votes. To remedy this problem (neglect of the black vote), Johnson states that in 1997 he "went early at the black vote" (Johnson 1998). He contends that in 1997 he "made a conscious effort to get the black vote." Johnson began his campaign a year prior to the 1997 Democratic primary for mayor. His strategy consisted of walking every block of the city to solicit the support of voters. In Johnson's view, the emphasis in 1997 was on attracting a black base. Glenda Glover, a member of Johnson's strategy team, indicates that Johnson's skills as an urban planner were invaluable in his daily task of walking the streets (Glover 1999).

Johnson did not attempt to run two separate campaigns, one for blacks and one for whites. One white political observer, Rims Barber, Executive Director of Mississippi Human Services Agenda, a research and advocacy organization on behalf of the poor, stated in a personal interview that when Johnson visited the Belhaven community, a prominent white neighborhood, "[h]e did not tilt his hat ... and he also stated that it was not true that he was going to provide a gate around the community to protect them from crime" (Barber 1999). In an interview with The Clarion Ledger, Johnson said, "I wouldn't allow my opponents to make me run away from the fact that I was black, to run away from the fact that people, black people in particular, would take pride in electing the first black mayor of this city" (cited in Fisher 1997 A1, A19). Johnson pointed out that it would have been easy and dishonest of him to say what others have said to him, "[w]hen I look at people I don't see race" (cited in Fisher 1997, 19A). Johnson continued, "[i]n America in 1997, I just don't think that's the case. I think we do see race. And I have to admit that and move from there" (cited in Fisher 1997, 19A). In suggesting that Johnson ran a racespecific campaign, local radio talk show host Frank Bluntson stated that Johnson was "blacker" in 1997 than in 1993 (Bluntson 1999). Additional evidence supporting the notion that Johnson ran a race-specific campaign is provided in an editorial taken from The Clarion Ledger the day after the 1997 primary. "The racial aspect of the mayor's race cannot be ignored . . Johnson targeted the black community. Racially polarized voting is a political reality. His campaign recognized that and played to it" (The Clarion Ledger 1992, A8). Matt Friedman, a columnist for The Clarion Ledger, writes in an oped piece concerning Johnson, "[y]ou played the race card pretty significantly to win the election" (Friedman 1997, A13).

Johnson also was able to gain the support of some of the major black leaders in the black community who had not supported him in $1993 . \mathrm{He}$ 
was able to "forge a truce with Tisdale," and therefore eliminated negative coverage in the Jackson Advocate, as he had received in 1993 and at the beginning of the 1997 campaign. Moreover, there were paid advertisements for Johnson in the Jackson Advocate in 1997. The advertisements contained race-specific information. For example, in an advertisement printed in the April 17-23, 1997 edition, it was indicated that Johnson would "create a strong African American business community." More importantly, at the very bottom of the advertisement in larger bold font, it read, "Because It's Time for Jackson to Elect Its First African American Mayor!" In addition to the support of Tisdale, Johnson also received the support of Congressman Bennie Thompson, a well-respected politician and long-time civil rights activist.

Thompson's endorsement played a major role in Johnson's ability to attract black voters. Thompson, however, was not easily persuaded to support Johnson. Charlie Horn, a staff member for Thompson, stated that the Congressman initially held reservations about supporting Johnson. Horn mentioned during a personal interview in April 1999 that Thompson thought Johnson was a "weak candidate" and that his "message was one that was compromising ... one that catered more to the affluent community ... and one that was less attractive to people who needed a voice in government." Thompson also felt that Johnson was "trying to attract white supporters" and was therefore neglecting a large portion of the black community (Horn 1999). Theoretically, Johnson's strategy did not comport with the mobilization strategies traditionally adopted by blacks (see e.g., Morris 1975; Morrison 1987).

After strong consideration, Thompson allowed Horn, one of his most skillful staff workers, to join Johnson's campaign (Horn 1999). Horn was appointed to head the get-out-the-vote effort. Upon Horn's arrival, he found "no campaign strategy or structure" in place. As a former labor organizer for the A. Phillip Randolph Institute, Horn quickly began organizing the campaign. Horn's first goal was to "increase turnout in 59 overwhelmingly black precincts." In an effort to achieve this goal, Horn began a "canvassing or literature drop" campaign to increase Johnson's name recognition. This process entailed a door-to-door distribution of campaign literature. It also included days in which volunteers occupied street corners and waved Harvey Johnson campaign signs. Horn then met with Johnson to suggest that he craft a message that would connect with those voters who had been left out of the political and economic process. Horn advised Johnson to take on the aura of a Baptist preacher, and told him that his message had to "come from the gut," that blacks had to perceive him as sincere. Horn stated, "you got to connect with Aint Be' Ruth Chill'un," which translates into "you have got to connect with Aunt Baby Ruth's children." In other words, Horn's advice to Johnson was that he needed to craft his message to reach beyond the black middle class.

The strategy worked! While observing one of Johnson's speeches late in the campaign for the primary, Barber (1999) reports he was amazed that Johnson had the crowd "stirring." Barber said he had never seen Johnson stir-up a crowd before. Horn confirms Barber's story. He asserts that Johnson created such a high level of excitement that so many volunteers turned out to help with the campaign that some of them had to be turned away (Horn 1999).

The excitement created by Johnson's speeches created a movement within the black community. Indeed, Johnson claimed that this was all a part of the strategy, to "create a movement, a crusade-type environment" (cited in Fisher 1997, A19). When speaking to black audiences, Johnson did not invoke a militant style, but he did say that "[i]t's time! Its [sic] time for African American leadership to come to the forefront" (Johnson 1998). Similarly, when speaking to majority white audiences, Johnson would indicate at the outset of his speech that he was "a black man that wants to be mayor of this city, and if elected will still be a black man, but that did not mean that I could not govern the city better than a white man" (Johnson 1998). In Johnson's opinion, "whites who were offended, were not going to support him anyway" (Johnson 1998).

In his effort to galvanize the black community, Johnson would tell a story of an elderly black woman who was barely getting along, and whom he had asked to vote for him. The woman's response was "Baby don't worry! I may not see me a black president but I'm going to see me a black mayor!" On many occasions he would tell a story about "the foxes and the hounds ... if the hounds could outnumber the foxes then they could defeat the foxes." Additionally, he related a tale about "the rabbits and the hound, even the lowly rabbit, if it gets itself together, then it could beat 
Table 3. 1997 Mayoral Democratic Primary (Estimated Percentage of Vote by Race)

\begin{tabular}{|c|c|c|c|c|c|c|}
\hline & Johnson & Ditto & Frascogna & Coleman & Taylor & Wilson \\
\hline Blacks & $\begin{array}{l}77 \\
(.4)\end{array}$ & $\begin{array}{l}9 \\
(.3)\end{array}$ & $\begin{array}{l}3 \\
(.1)\end{array}$ & $\begin{array}{l}7 \\
(2.3)\end{array}$ & $\begin{array}{l}2 \\
(.02)\end{array}$ & $\begin{array}{l}1 \\
(.01)\end{array}$ \\
\hline $\begin{array}{l}\text { Whites } \\
\mathrm{N}=94\end{array}$ & $\begin{array}{l}19 \\
(.6)\end{array}$ & 52 & 24 & $\begin{array}{c}.1 \\
(.2)\end{array}$ & $\begin{array}{l}.3 \\
(.03)\end{array}$ & $\begin{array}{l}.2 \\
(.02)\end{array}$ \\
\hline
\end{tabular}

Note: Estimates were produced using Gary King's EI. Numbers in parenthesis are rounded estimated standard errors.

out the hound." He spoke of "black rabbits and white rabbits, rabbits in South Jackson and North Jackson." Finally, while Johnson admits that he employed a different campaign strategy in 1997, he contends that the issues did not change, (i.e., crime, economic development, and race relations). The presentation of these issues, however, did change, as a result of the change in Johnson's style. These changes no doubt improved his support among black voters. In 1997, Table 3 indicates that Johnson captured an estimated 77 percent of the black vote in contrast to only 46 percent in 1993. While voter turnout among blacks actually decreased from an estimated 45 percent in 1993 (see Table 2) to 26 percent in 1997, it is estimated that blacks constituted a substantial majority ( 65 percent) of those voting in the 1997 primary (compared to only 47 percent in 1993).

\section{Racial Voting in the 1997 Democratic Primary}

The 1997 mayoral campaign drew a crowded field of twelve candidates. This pool of candidates was comprised of six Democrats, four Republicans, and two independents. The field was evenly split along racial lines, six whites and six African Americans. Among the Democrats, three were white and three were African American. The white Democrats included the incumbent mayor, Ditto, an attorney, Pat Frascogna, and a retired attorney, Lewis Wilson. The African American Democrats were Johnson, plus a state legislator, Mary Coleman, and a truck driver, Charles Taylor. Of the four Republicans, only one was African American, James Meredith, a civil rights activist and most notably, the first African American student admitted to the University of Mississippi. The three white Re- publicans included an insurance salesman, Aaron Dupuy III, the co-owner of A-1 Pallet, Charlotte Reeves, and, once again, Al Roland, now a driver for Mississippi Seafood Exchange. The two independent candidates were African American: a teacher, urban planner, and 1996 Democratic congressional candidate Kevin Antoine, and Ivory Phillips, a Jackson State University Professor.

As indicated by Table 3, Johnson's (African American) percentage of the black vote in the 1997 primary is estimated to have been 77 , which is 31 percentage points higher than that estimate for 1993. Johnson was followed by Ditto (white), with nine percent of the black vote, Mary Coleman (African American; not to be confused with the Professor cited above), a state legislator, with seven percent, Pat Frascogna (white), an attorney with four and Charles Taylor (African American), a truck driver, with two. Lewis Wilson (white), an attorney, is estimated to have received approximately one percent of the black vote.

Johnson's victory was boosted by the 19 percent of the white vote that he is estimated to have received, an increase of 12 percentage points over that estimate for the 1993 primary. The candidate of choice for white voters was the incumbent mayor Ditto, who received an estimated 52 percent of their votes. Frascogna received the second highest white vote, with 24 percent, followed by Coleman with four percent. Both Wilson and Taylor received virtually no white support.

\section{The General Election}

Johnson faced Charlotte Reeves, the winner of the Republican primary, in the 1997 general election. Reeves, a white businesswoman with no prior political experience, won the Republican primary easily, with 70 percent of the vote. Johnson received the endorsements of former mayor Kane Ditto and Kevin Antoine, a former mayoral candidate, and also those of The Clarion Ledger and the Jackson Advocate, neither of which had endorsed him in 1993. Reeves was endorsed by Pat Frascogna, a candidate in the Democratic primary, and Governor Kirk Fordice, a Republican. Regardless of who would emerge as the winner of the general election, history was to be made in Jackson. Either the first African American, or the first woman, would be elected mayor. In the end, Johnson prevailed, receiving 70 percent of the overall vote $(30,310$ to 13,282$)$. 


\section{Racially Polarized Voting in the 1997 General Election}

Blacks overwhelmingly supported Johnson in the 1997 general election by casting an estimated 98 percent of their votes for him; Reeves received only two percent. Whites, on the other hand, preferred Reeves. But whites were more willing to cross over in the general election than they had done in either the 1993 or 1997 Democratic primaries, providing Johnson with 35 percent of their votes.

\section{Conclusion}

In 1997, Harvey Johnson became the first African American to be elected as mayor in Jackson, Mississippi. Johnson's victory made national news, given the state's infamous history in the area of race relations and its virulent opposition to the civil rights movement. The day after Johnson's victory, The Clarion Ledger ran a story implying that he had run a deracialized campaign in 1993 and lost, then ran a racialized campaign in 1997 and won. The primary purpose of this article was to test this contention. Indeed, Johnson's (1997) style and mobilization tactics contrasted sharply with those in 1993. In addition, while the issues were the same for both elections, his presentation of them was different. Johnson spoke to the issues in a way that was more appealing to the entire black community in 1997. He also did not attempt to send mixed messages to the black and white communities. When it came down to the issues, what was said in the black community was also said in the white community. While I was not able to obtain copies of Johnson's speeches, which would have enabled me to make quantitative comparisons of the use of racial cues in those speeches, the qualitative evidence presented in this article clearly shows that Johnson ran a more race-specific campaign in 1997 compared to 1993. In particular, Johnson's style was different in that he confronted the issue of race and his mobilization tactics were more aggressively targeted to the black community.

One of the weaknesses associated with studies examining the deracialization construct is that this body of research fails to take into consideration contextual effects such as the media or the campaigns run by other black candidates. In 1993, Johnson was hurt by his failure to participate in a community-based campaign for the election of a black mayor. Johnson's decision not to participate in the CCPJ played a major role in his defeat in the 1993 primaries. Whether it was simply the case that Johnson was unable to capture the vote of those mainly black citizens who supported the coalition, or the fact that the emerging candidate from the $\mathrm{Co}$ alition, Henry Kirksey, was able to fracture the black vote, Johnson was hurt by his lack of participation. This event was probably more important in 1993 than in 1997 primarily because of the racial demographics of the city in 1993. The 1990 census suggests that the black population was approximately 56 percent, while the 2000 Census puts the black population at approximately 71 percent. To be sure, the campaign styles adopted by Johnson played key roles in his defeat and victory in 1993 and 1997, respectively. However, it clearly was not the sole variable explaining these two outcomes. Kirksey's pro-black agenda surely siphoned off some of the black votes, as is indicated by the findings reported here, and white flight was clearly a factor in 1997.

In closing, the deracialized tactics employed by Johnson in 1993 produced minimal support from Whites, while gaining Johnson less than half the votes cast by blacks. These findings run counter to those previously reported in studies of deracialized campaigns that demonstrate that black candidates who have adopted this strategy have been successful (see e.g., Jones and Clemons 1993; Llorens, Parsons, and Perry 1996; Schexnider 1990; Winn and Palmer 1996).

\section{Notes}

The author would like to thank Richard L. Engstrom, Sharon Wright-Austin, Robert Albritton, L. Judson Jeffries, Neal Allen, Christopher Lawrence, and the anonymous peer reviewers. The author would especially like to thank his father, the late Dan Orey, Jr. for his inspiration and guidance. This project was funded by the Southern Regional Education Board Doctoral Scholars Program and the Earnest G. Chachere Fellowship at the University of New Orleans. The author retains responsibility for errors within the manuscript.

${ }^{2}$ The black population was 56 percent according to the 1990 census.

${ }^{3}$ It should also be noted that Wright-Austin and Middleton (2004) have also applied the deracialization construct to Latino campaigns.

${ }^{4}$ The Church's long-standing political role stretched back into slavery, when it had constituted the only institution to which blacks could turn. After blacks migrated north to the big cities, the church's political role became all the more pronounced (Frazier 1964, 169).

${ }^{5}$ A large portion of Bennie Thompson's district overlapped with the city of Jackson. Hence, Thompson's racialized campaign helps to buttress my argument discounting the usefulness of a deracialized campaign in Jackson, Mississippi. 
${ }^{6}$ This new method developed by King replaces the previous reliance on ecological regression to create such estimates, and now serves as the leading method for ecological inference in the social sciences.

${ }^{7}$ King's method makes three assumptions: (1) that each precinct's black and white percentages together are one drawn from bivariate normal distribution, truncated so that both fall within the 0 percent and 100 percent range; (2) in each precinct, the estimated black vote $\left(B_{i}^{b}\right)$ and the estimated white vote $\left(B_{i}^{w}\right)$ are mean independent of racial density; and (3) that the values of the proportion voting $\left(\mathrm{T}_{\mathrm{i}}\right)$ "in different precincts are independent after conditioning on $\mathrm{X}_{i}$ " (King 1997, 94).

${ }^{8}$ The current analysis employed EI, version 1.9 (Benoit and King 2000), available online at http://gking.harvard.edu

${ }^{9}$ The primary system in Jackson is an open-system in which the voter chooses which party primary (i.e., Democratic or Republican) he/she wants to vote in on Election Day.

\section{References}

Aden, Marky. 1992. "Coalition for Black Mayor Endorses Kirksey.” The Clarion Ledger. August 20, A1

Albritton, Robert B., George Amedee, Keenan Grenell, and Don-Terry Veal. 1996. "Deracialization and the New Black Politics." In Race, Politics and Governance in the United States, edited by Huey L. Perry. Gainesville, FL: University Press of Florida. 96-106.

Barber, Rims. 1999. Personal interview. Jackson, Mississippi. April.

Benoit, Kenneth, and Gary King. 2003. "Ezl: A(n Easy) Program for Ecological Inference." Accessed on August 17, 2006. Available online at http://gking.harvard.edu

Bluntson, Frank. 1999. Conversation with the author. Jackson, MS, 8 April.

Campbell, Sarah. 1992. "Johnson Enters Mayoral Race Promising a Better Jackson." The Clarion Ledger. October 30, A1.

Chappell, Kevin. 1997. "Harvey Johnson: First Black Mayor of Jackson, Mississippi." Ebony (LII) (August): 76-80.

Coleman, Mary D., and Kenya A. Hudson. 2001. "Deracialization Strategy, Racial Symbolism, and Political Context in Mississippi Politics." In Politics in Mississippi, Second Edition, edited by Joseph P. Parker. Salem: Sheffield Publishing Company.

Fisher, Grace Simmons. 1997. "Experience, Race Lifted Johnson." The Clarion Ledger. June 8, A1, A19.

Frazier, E. Franklin. 1964. The Negro Church in America. New York: Schocken Books.

Friedman, Matt. 1997. "Hint to Harvey Johnson: Subdue to Temptation, Assume Moral Leadership." The Clarion Ledger. May 9, 13A.

Glaser, James M. 1996. Race, Campaign Politics, and the Realignment in the South. New Haven, CT: Yale University.

Glover, Glenda. 1999. Conversation with the author. Jackson, MS, 10 March.

Grimshaw, William. 1992. Bitter Fruit. Chicago: University of Chicago Press.
Grofman, Bernard, Lisa Handley, and Richard G. Niemi. 1992. Minority Representation and the Quest for Voting Equality. New York: Cambridge University Press.

Hamilton, Charles. 1973. "Full Employment as a Viable Issue." In When the Marching Stopped: An Analysis of Black Issues in the 70s, edited by Andrew F. Brimmer. New York: The National Urban League. 87-91.

1977. "Deracialization: Examination of a Political Strategy." First World (March/ April): 3-5.

Horn, Charlie. 1999. Personal interview. Jackson, Mississippi. April.

Howard, J. Lee. 1993. "Black Vote Would Be Factor in Runoff." The Clarion Ledger. April 27, A1.

Johnson, Harvey. 1998. Conversation with the author. Jackson, MS, 17 August.

Jones, Charles E., and Michael L. Clemons. 1993. "A Model of Racial Crossover.” In Dilemmas of Black Politics, edited by Georgia Persons. New York: Harper Collins College Publishers. 66-84.

King, Gary. 1997. A Solution to the Ecological Inference Problem. Princeton, NJ: Princeton University Press.

Kirksey, Henry. 1999. Telephone conversation with the author, March 23.

Llorens, James L., Sharon K. Parsons, and Huey L. Perry. 1996. "The Election of Troy Carter to the Louisiana House of Representatives." In Race, Politics, and Governance in the United States, edited by Huey L. Perry. Gainesville, FL: University Press of Florida. 107-23.

McCormick, J. P., II. 1989. "Black Tuesday and the Politics of Deracialization." Presented at the symposium Blacks in the November '89 Elections: What is Changing? of The Joint Center for Political Studies, Washington, DC. December 5.

McCormick, J. P., II, and Charles E. Jones. 1993. "The Conceptualization of Deracialization.” In Dilemmas of Black Politics, edited by Georgia Persons. New York: Harper Collins College Publishers. 66-84.

Morris, Aldon. 1975. The Origin of the Civil Rights Movement. New York: Harper and Row.

Morrison, K. C. 1987. Black Political Mobilization. Albany, NY: S.U.N.Y. Press.

Palmquist, Bradley, and D. Stephen Voss. 1997. "Separating the Strands of Southern Political Behavior: The Case of Louisiana." Presented at the 1997 Annual Meeting of the Southwest Political Science Association, New Orleans, LA. March 26-29.

Parker, Frank. 1990. Black Votes Count: Political Empowerment in Mississippi after 1965. Chapel Hill: University of North Carolina Press.

Perry, Huey. 1990. "Recent Advances in Black Electoral Politics." PS: Political Science and Politics 23 (2): 141-42.

Pierannunzi, Carol A., and John D. Hutcheson, Jr.. 1996. "The Rise and Fall of Deracialization: Andrew Young as Mayor and Gubernatorial Candidate." In Race Politics, and Governance in the United States, edited by Huey L. Perry. Gainesville, FL: University Press of Florida. 96-106. 
Pohlman, Marcus, and Michael Kirby. 1996. Racial Politics at the Crossroads. Knoxville, TN: University of Tennessee Press.

Ransom, Bruce. 1987. "Black Independent Electoral Politics in Philadelphia and the Election of Mayor W. Wilson Goode." In The New Black Politics, edited by Michael Preston, Lenneal J. Henderson, Jr., and Paul L. Puryear. White Plains, NY: Longman Press. 256-93.

Reeves, Keith. 1997. Voting Hopes or Fears?: White Voters, Black Candidates and Racial Politics in America. New York: Oxford University Press.

Schexnider, Alvin J. 1990. "The Politics of Pragmatism: An Analysis of the 1989 Gubernatorial Election in Virginia." Urban Affairs Quarterly 27 (2): 216-22.

Shamsid-Deen, Ali. 1999a. Conversation with the author. Jackson, MS, 18 March. . 1999b. Telephone conversation with the author, 25 March.

Stringfellow, Eric. 1992. " $2^{\text {nd }}$ group forms to help elect '93 black mayoral candidate." The Clarion Ledger, May 7, A1.

Stringfellow, Eric. 1997. "Black Coalition Chairman Adamant on Closed Door." The Clarion Ledger. May 12, B1.

The Clarion Ledger. 1992. "Alliance Hopes to Select Black Mayoral Candidate for Jackson Today." August 29, B1.

The Clarion Ledger. 1997. "Editorial: Harvey Johnson.” May 7, 8A.

Tisdale, Charles. 1999. Personal interview. Jackson, Mississippi. 17 March.

Uthoff, Christine. 1992. "Ousted Officer Joins Danks' Mayoral Campaign.” The Clarion Ledger. December 13, B1.

Wilson, William Julius. 1990. "Race Neutral Policies and the Democratic Coalition." The American Prospect 1: 74-81.

Winn, Mylon, and Errol G. Palmer. 1996. "The Election of Norman B. Rice as Mayor of Seattle." In Race Politics, and Governance in the United States, edited by Huey L. Perry. Gainesville, FL: University Press of Florida. 82-95.

Wright, Sharon. 1996. "The Deracialization Strategy and African American Candidates in Memphis Mayoral Elections." In Race, Politics and Governance in the United States, edited by Huey L. Perry. Gainesville, FL: University Press of Florida. 151-64.

Wright-Austin, Sharon, and Richard Middleton. 2004. "The Limitations of the Deracialization Concept in the 2001 Los Angeles Mayoral Election." Political Research Quarterly 57 (2): 283-93.

Yancey, Dwayne. 1988. When Hell Froze Over. Roanoke, VA: Taylor Publishing Co. 